\title{
A review of international green power markets: recent experience, trends, and market drivers
}

\author{
L. Bird $^{\mathrm{a}, *}$, R. Wüstenhagen ${ }^{\mathrm{b}}, \mathrm{J}$. Aabakken ${ }^{\mathrm{a}}$ \\ a National Renewable Energy Laboratory, 1617 Cole Boulevard, Golden, CO 80401, USA \\ ${ }^{\text {b }}$ SAM Private Equity, Zollikerstrasse 60, CH-8702 Zollikon, Switzerland
}

Received 18 May 2002; accepted 19 May 2002

\begin{abstract}
Green power marketing - the act of differentially selling electricity generated wholly or in part from renewable sources - has emerged in more than a dozen countries around the world. Almost two million customers worldwide buy green power today. This paper reviews green power marketing activity in Australia, Canada, Japan, the US, and in a number of countries in Europe to gain an understanding of consumer demand for electricity generated from renewable sources. It also examines key factors that influence market penetration of green power products, such as product designs, pricing, incentives, marketing strategies, policies, and product certification.

(C) 2002 Elsevier Science Ltd. All rights reserved.
\end{abstract}

Keywords: Deregulation; Green power marketing; Green pricing; Customer choice

\section{Contents}

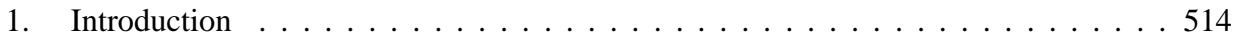

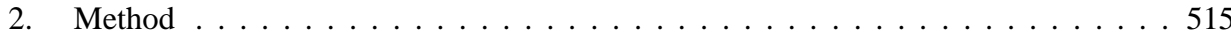

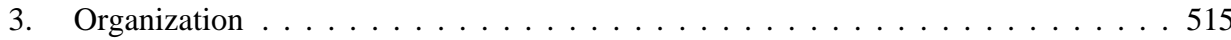

* Corresponding author. Fax: +1 3033847411.

E-mail addresses: Lori_Bird@nrel.gov (L. Bird); rolf@sam-group.com (R. Wüstenhagen); jorn_aabakken@nrel.gov (J. Aabakken). 


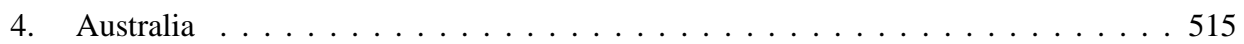

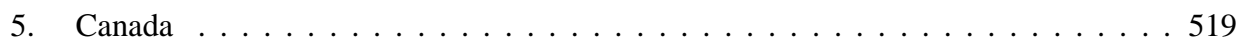

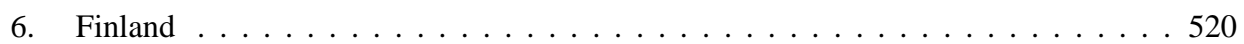

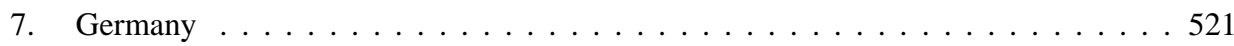

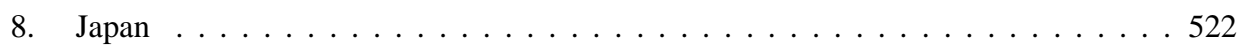

9. The Netherlands . . . . . . . . . . . . . . . . . . . 523

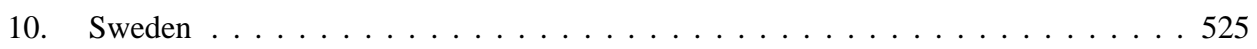

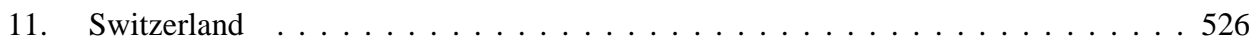

12. United Kingdom . . . . . . . . . . . . . . . . . . . . . . 527

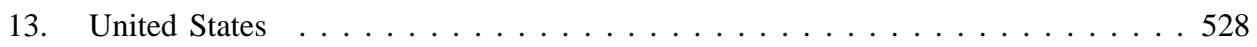

14. Other countries . . . . . . . . . . . . . . . . . . . . . 529

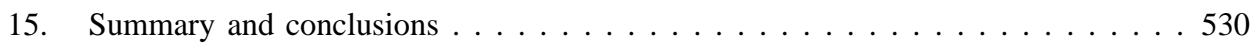

\section{Introduction}

Throughout the world, many electricity customers are gaining the ability to choose their electricity providers. In some cases, cleaner power options are available. Green power marketing - the act of differentially selling electricity generated wholly or in part from renewable sources-has emerged in more than a dozen countries across the globe. In addition to enabling customers to choose how their power is generated, the development of markets for green power are important because they provide renewable energy developers with access to an additional revenue stream to cover the above-market costs of generating electricity from renewable sources.

Currently, green power is offered to retail customers in Australia, Canada, Japan, the US, and a number of European countries. The purpose of this article is to: (1) survey international green power marketing activity; (2) determine which particular market structures, marketing strategies, policies, or other factors lead to more robust green power markets; and (3) determine if there are lessons and concepts that can be shared to aid in the development of markets. Specifically, we examine the following questions. Have some countries achieved higher rates of market penetration? Is customer response affected by the price of green power products? Does it matter whether the market is open to competition or whether customers must switch suppliers to purchase a green product? Do certain market rules encourage or inhibit growth of the green power market? Are there mechanisms or institutions that have been particularly 
successful in facilitating the sale of green power, such as product certification programs or renewable energy certificate-trading programs? And finally, are there particular renewable energy policies that have stimulated a greater level of green power marketing activity?

\section{Method}

In conducting this research ${ }^{1}$, we identified countries in which green power marketing has been underway for several years and countries in which the market is just emerging. We obtained information on market activity through literature reviews, news reports, and discussions with marketers, environmental stakeholders, and market analysts, as well as representatives of product certification programs, utilities, and government agencies. We also conducted Internet searches to obtain information on the leading green power marketers. Whenever possible, we collected information on the number of marketers, the types of products offered, product content and pricing, consumer response ${ }^{2}$, and new renewable resource development stimulated by green power purchases. In many cases, certification programs provided much of the data on product offerings and response rates. We also relied on reviews by local green power marketing experts to ensure the accuracy of our data and analyses.

\section{Organization}

The following sections summarize green power markets in the countries that show the highest level of activity, namely Australia, Canada, Finland, Germany, Japan, the Netherlands, Sweden, Switzerland, the UK and the US. We also briefly review seven other European countries with emerging green power markets (see Fig. 1). Our assessment of the level of green power marketing activity for each country we survey is summarized in Table 1. We conclude with a comparison of the green power marketing experience in the countries reviewed here and discuss key factors that influence green power market development.

\section{Australia}

Utilities first began to market green power to customers in Australia in the mid1990s. Today, incumbent retail energy suppliers offer green power options in Victoria, New South Wales, Queensland, the Australian Capital Territory (ACT), South

${ }^{1}$ The research presented here is derived from a report prepared for the US Department of Energy's (DPE) Office of Energy Efficiency and Renewable Energy [37].

${ }^{2}$ Estimates of green power customers are often based on marketer claims and, thus, have some degree of uncertainty. Whenever possible, we sought independent verification, but all remaining inaccuracies are solely the responsibility of the authors. 


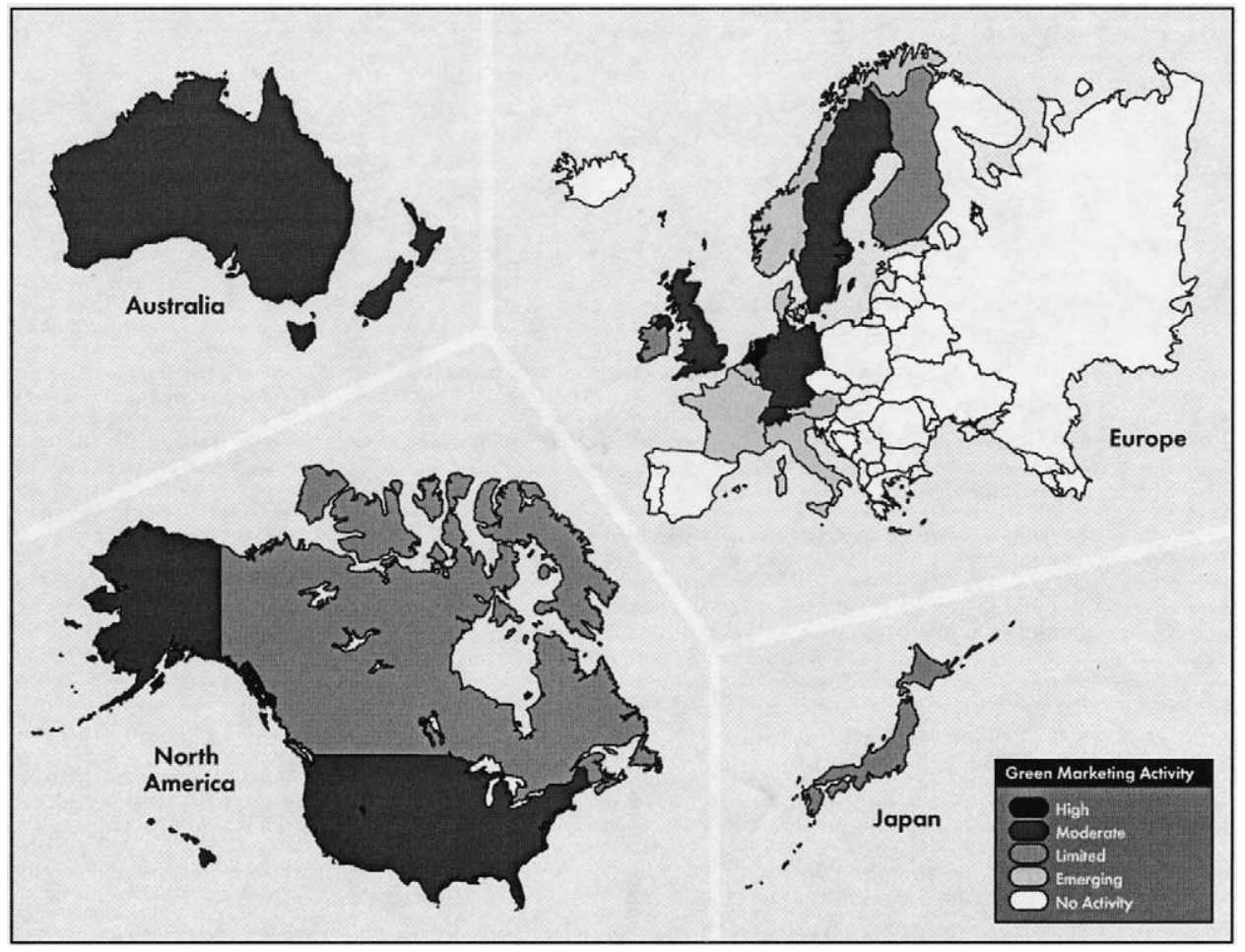

Fig. 1. Countries with current of emerging green power markets.

Australia, and Western Australia, giving more than 95\% of the country's retail customers the option to purchase green power [1].

In Australia, there are about 20 green power products available on the market, with about three-quarters of these accredited by the National Green Power Accreditation program. A few marketers recently began offering uncertified products, particularly to nonresidential customers [2]. In addition, one green power provider offers a contribution-based renewable energy product, through which customers can contribute to a fund to develop new renewables. Contribution programs have been phased out of the national accreditation program, because they have "proven less effective in the installation of new renewable generators," according to the Sustainable Energy Development Authority (SEDA) [3].

Most energy-based products consist of biomass power blended with other renewable sources such as wind, solar, and hydro. Marketers typically offer customers the option of purchasing 50 or $100 \%$ of their power from renewable sources, with a few companies offering smaller purchase options, such as 10 or $25 \%$. Recently, suppliers have offered products with at least $70 \%$ new renewable energy content, which is a requirement of the national certification program. The requirement increased to $80 \%$ new renewable energy content as of 2002. Most residential green power products are priced at $3 \mathrm{~A} \phi / \mathrm{kWh}-5 \mathrm{~A} \phi / \mathrm{kWh}$ (US $2-3 \phi / \mathrm{kWh}$ ) above standard electricity rates 
Table 1

Market status and green power marketing activity

\begin{tabular}{|c|c|c|c|}
\hline Country & Market status & $\begin{array}{l}\text { Green marketing } \\
\text { activity }\end{array}$ & $\begin{array}{l}\text { Start of green power market } \\
\text { activity }\end{array}$ \\
\hline Australia & $\begin{array}{l}\text { Most customers have retail } \\
\text { choice; some states have delayed } \\
\text { restructuring }\end{array}$ & Moderate & $\begin{array}{l}\text { First utility programs } \\
\text { launched in mid-1990s }\end{array}$ \\
\hline Austria & $\begin{array}{l}\text { Market fully open to competition } \\
\text { since October } 2001\end{array}$ & Emerging & $\begin{array}{l}\text { First green power offerings } \\
\text { launched in } 2001\end{array}$ \\
\hline Belgium & $\begin{array}{l}\text { Undergoing restructuring, large } \\
\text { and mid-sized businesses have } \\
\text { retail access; green electricity } \\
\text { customers have choice in Flemish } \\
\text { region }\end{array}$ & Emerging & To be determined \\
\hline Canada & $\begin{array}{l}\text { Partially open to competition; } \\
\text { Alberta has retail competition, } \\
\text { Ontario opened mid- } 2002\end{array}$ & Limited & $\begin{array}{l}\text { First utility programs } \\
\text { launched in late } 1990 \mathrm{~s}\end{array}$ \\
\hline Denmark & $\begin{array}{l}\text { Large customers gained direct } \\
\text { access in 1999, all customers will } \\
\text { have retail choice starting in } 2003\end{array}$ & Emerging & $\begin{array}{l}\text { First utility programs } \\
\text { launched in late } 1990 \mathrm{~s}\end{array}$ \\
\hline Finland & $\begin{array}{l}\text { Market opened to large customers } \\
\text { in 1995, residential customers } \\
\text { gained access without incurring } \\
\text { fees in } 1998\end{array}$ & Limited & $\begin{array}{l}\text { First competitive products } \\
\text { launched in late 1990s }\end{array}$ \\
\hline France & $\begin{array}{l}\text { Undergoing restructuring, only } \\
\text { large customers have direct access } \\
\text { to date. No schedule has been set } \\
\text { for residential access to } \\
\text { competitive suppliers }\end{array}$ & Emerging & To be determined \\
\hline Germany & $\begin{array}{l}\text { Market opened to all customers in } \\
\text { 1998, competitive offerings } \\
\text { available to residential customers } \\
\text { since } 1999\end{array}$ & Moderate & $\begin{array}{l}\text { First utility programs offered } \\
\text { in mid-1990s, first } \\
\text { competitive products launched } \\
\text { in } 1998\end{array}$ \\
\hline Ireland & $\begin{array}{l}\text { Green electricity customers and } \\
\text { large customers have had access } \\
\text { to competitive suppliers since } \\
\text { February } 2000\end{array}$ & Limited & $\begin{array}{l}\text { First competitive marketers } \\
\text { appeared in } 2000\end{array}$ \\
\hline Italy & $\begin{array}{l}\text { Undergoing restructuring, only } \\
\text { large customers have direct access } \\
\text { to date. Plans for smaller } \\
\text { consumers under development }\end{array}$ & Emerging & To be determined \\
\hline Japan & $\begin{array}{l}\text { Legislature is studying } \\
\text { restructuring options, but no firm } \\
\text { plans to implement retail choice } \\
\text { currently }\end{array}$ & Limited & $\begin{array}{l}\text { First green power options } \\
\text { appeared in 1999-2000 }\end{array}$ \\
\hline The Netherlands & $\begin{array}{l}\text { Large and mid-sized companies } \\
\text { have retail access, green } \\
\text { electricity customers gained retail } \\
\text { access in July 2001, all residential }\end{array}$ & High & $\begin{array}{l}\text { First utility programs formed } \\
\text { in } 1995 \text {, all } 12 \text { utilities have } \\
\text { offered programs since } 1999\end{array}$ \\
\hline
\end{tabular}

(continued on next page) 
Table 1 (continued)

\begin{tabular}{|c|c|c|c|}
\hline Country & Market status & $\begin{array}{l}\text { Green marketing } \\
\text { activity }\end{array}$ & $\begin{array}{l}\text { Start of green power market } \\
\text { activity }\end{array}$ \\
\hline Norway & $\begin{array}{l}\text { Market opened to competition in } \\
\text { 1991, all customer were able to } \\
\text { switch suppliers without incurring } \\
\text { fees by } 1999\end{array}$ & Emerging & $\begin{array}{l}\text { First competitive products } \\
\text { launched in late } 1990 \mathrm{~s}\end{array}$ \\
\hline Sweden & $\begin{array}{l}\text { Market opened to competition in } \\
\text { 1996, all customers were able to } \\
\text { switch suppliers without incurring } \\
\text { fees by } 1999\end{array}$ & Moderate & $\begin{array}{l}\text { First green power products } \\
\text { appeared in } 1996 \text { with start of } \\
\text { competition }\end{array}$ \\
\hline Switzerland & $\begin{array}{l}\text { Restructuring plans still pending } \\
\text { in legislature (subject to } \\
\text { referendum in fall of 2002) }\end{array}$ & Moderate & $\begin{array}{l}\text { First utility programs were } \\
\text { launched in mid-1990s }\end{array}$ \\
\hline UK & $\begin{array}{l}\text { Large customers gained direct } \\
\text { access in } 1994 \text { and residential } \\
\text { customers gained retail access in } \\
1999\end{array}$ & Moderate & $\begin{array}{l}\text { First utility programs } \\
\text { launched in } 1989 \text {, second } \\
\text { generation of products in late } \\
\text { 1990s }\end{array}$ \\
\hline US & $\begin{array}{l}\text { Partially open to competition; } \\
\text { more that } 16 \text { states have or are in } \\
\text { the process of implementing retail } \\
\text { competition, seven have delayed } \\
\text { restructuring, California has } \\
\text { ceased direct access }\end{array}$ & Moderate & $\begin{array}{l}\text { First utility programs } \\
\text { launched in early to mid- } \\
\text { 1990s, first competitive } \\
\text { products offered in } 1998\end{array}$ \\
\hline
\end{tabular}

(potentially a $30 \%$ premium). Products are also typically available to business customers at negotiated quantities and rates.

As of June 2001, a total of about 68,000 customers were purchasing green power, with about 57,000 of those purchasing accredited products. More than three-quarters of the green power sales were to customers in New South Wales and Queensland. Total sales of green energy were approximately 460 million $\mathrm{kWh}$ for the 1-year period between July 2000 and June 2001, with business customers representing nearly half of this. Since 1997, when data first became available, green power sales have increased tenfold. The number of customers has also climbed considerably during this period. For example, between 1999 and 2000, the number of green power customers increased by more than $50 \%$. There was a slight dip in the number of customers participating in accredited programs in 2000/2001 - because the national accreditation program stopped certifying contribution programs in 2000 , those customers were dropped from the totals. Overall, green power customers currently represent nearly $1 \%$ of the residential electricity market $[3,4]$.

In sum, there are a relatively large number of green power marketers, and nearly all customers in Australia have access to green power. The Australian green power market has grown steadily during the past several years, but market penetration levels are still relatively modest at about $1 \%$. The most successful utility green power programs have achieved participation rates of $2-3 \%$ of the customers in their franchise service territories. The government-run certification program has played a sig- 
nificant role in shaping green power product offerings, particularly with respect to new renewable energy content. The program's aggressive new renewable standard is stimulating growth in renewable energy capacity and should continue to do so over time. Based on recent growth patterns, it is likely that participation in green power programs will also continue to climb. It remains to be seen what impact a government-imposed renewable purchase obligation will have on consumer participation in voluntary programs. At the same time, the certificate-trading program, established to implement the purchase obligation, could facilitate green power transactions and encourage further development of the market.

\section{Canada}

Until recently, the Canadian market for green power has been largely limited to Alberta, the first province to institute retail competition. The first products were introduced in the late 1990s by incumbent utilities, Epcor and Enmax. Currently, these companies collectively serve about 6000 green power customers. In addition, Vision Quest, which supplies wind power to one of the utilities, also offers a wind power product to retail customers in other parts of the province.

Recently, several marketers have launched green power products or announced plans to offer green power to customers in Ontario, where retail competition recently took effect. For example, Ontario Power Generation is offering green power to large commercial and industrial customers and, at the wholesale level, to distribution utilities [5]. It offers three green power products, which differ in respect to the fraction of power generated from certified renewable facilities commissioned before and after 1991. In early 2001, the company established an operating unit called 'Evergreen Energy' to develop and supply power from renewable sources. In addition, Toronto Hydro Energy Services recently announced a green power option for residential and business customers, called Citisource Green Power [6]. The product is sold in blocks and supplied from wind and certified hydro resources. The company is teaming with the Toronto Renewable Energy Co-operative to build two wind turbines on Toronto's waterfront, which are expected to be operational by the fall of 2002. Other existing green power marketers have indicated interest in offering green power options.

In areas without retail access, at least two marketers recently began offering green power products and another announced its intention to offer a product in the fall of $2002^{3}$. In April 2002, SaskPower, a municipal utility in Saskatchewan, began offering a wind power option to residential and business customers. The power comes from two wind farms with a combined capacity of nearly $17 \mathrm{MW}$, much of which is supplying the power needs of government facilities in the province. In late 2001, Maritime Electric, a utility in Prince Edward Island, launched a green power product, which

\footnotetext{
${ }^{3}$ In recent years, two municipal utilities-Cambridge and North Dumfries Hydro of Ontario and West Kootenay Power of British Columbia-supplied a small number of customers in British Columbia and Ontario with green power, but are no longer offering green power products.
} 
is supplied from a new 5.2 MW wind project. And in British Columbia, BC Hydro recently announced its intention to offer green power to commercial and industrial customers in the fall of 2002 [7]. Wind power projects are also being developed in Nova Scotia and Newfoundland, setting the stage for possible green power marketing efforts in those regions [8,9].

Price premiums for green power products range from $3.5 \mathrm{C} \notin / \mathrm{kWh}$ to $9.8 \mathrm{C} \notin / \mathrm{kWh}$ (-US $2-6 \varnothing / \mathrm{kWh})$. Most of the products are supplied primarily with wind power, but at least one marketer offers a blend of biomass, solar, and wind.

Although there has been an increase in the amount of green power marketing activity in Canada recently, there are still a relatively small number of utilities and marketers offering products. Until recently, most of the activity centered around Alberta, the first market to open to competition. In that region, two incumbent utilities have managed to subscribe several thousand customers, representing about $1 \%$ of their respective customer bases. Marketing efforts are now beginning to spread to other regions. New markets are developing in Saskatchewan and Prince Edward Island, aided by government green power purchases. Growth is also expected in the Ontario market, where several marketers have begun or are planning to offer green power when competition begins.

\section{Finland}

Currently, there are at least 30 companies offering green power in Finland. Some green power providers offer more than one product, such as a wind power option and a blend of certified renewables. More than three-quarters of all products feature wind power. A number of suppliers offer power generated from biomass resources, such as wood waste. Helsinki Energy and several other suppliers offer green power in $1000 \mathrm{kWh}$ blocks, which have been popular among customers.

According to a survey conducted by the Department of Marketing at the University of Vaasa, the number of green power customers increased by about $60 \%$ between 1999 and 2000. As of May 2001, about 6000 customers, including about 300 small and mid-sized nonresidential customers, were purchasing some form of green power [10]. Only about one-third of the customers switched electricity providers to purchase green power. Of the total, about 2000 were purchasing certified products. Since then, the number of customers purchasing certified green power products is estimated to have grown to about 4000 (as of early 2002) bringing the total number of customers to about 8000 [11].

Collectively, sales of certified green power represented about $0.2 \%$ of all electricity sold (about 78 TWh) in Finland as of the spring of 2001. Data on sales of uncertified green energy are not available.

Price premiums for green power have been modest, with many products priced below standard offer service. On average, residential consumers have been able to purchase green power at a discount of about $2 \mathrm{p} / \mathrm{kWh}-5 \mathrm{p} / \mathrm{kWh}(-\mathrm{US} 0.3-0.8 \not / \mathrm{kWh})$ compared to the cost of standard offer service. Of those products offered at a premium, the highest premiums reached about $4 \mathrm{p} / \mathrm{kWh}(\sim \mathrm{US}, 0.6 \notin / \mathrm{kWh})$ for certified 
renewable energy blends and $6 \mathrm{p} / \mathrm{kWh}(\sim \mathrm{US} 0.8 \notin / \mathrm{kWh})$ for wind power. The largest discounts offered for certified green power blends have been about $10 \mathrm{p} / \mathrm{kWh}(\sim \mathrm{US}$ $1.5 \notin / \mathrm{kWh})[10]$.

Despite low price premiums or the potential to achieve savings, green power sales have been relatively low. According to the University of Vaasa study, some of the factors that have limited the adoption of green power in Finland are that consumers inaccurately perceive the cost of green power to be high, they lack an understanding of what green electricity is and how to purchase it, and marketers have not adequately marketed green power products.

In summary, customer response has been modest to date, yet the total number of green power customers has grown steadily during the past two years. In the future, at least modest growth in green power sales is likely, given that there are a relatively large number of marketers and many offer green power products that cost less than conventional electricity service.

\section{Germany}

Utilities were the first to offer green power options to customers, with the launch of the first green pricing programs in the mid-1990s. Following the introduction of competition in 1998, a number of new green power marketers introduced products, while incumbent utilities repositioned their programs for the newly competitive market environment [38]. Today, more than 135 marketers supply green power to an estimated 325,000 customers in Germany. The majority of green power customers buy $100 \%$ hydropower products offered by one of two companies, Naturenergie and E.On. About 95 of the 900 municipal utilities in Germany offer one or more green power products. In addition, a number of competitive marketers, including subsidiaries of existing utilities, as well as start-ups with roots in the environmental community, such as Naturstrom and Greenpeace Energy, offer green power. Another start-up, Lichtblick, has recently significantly increased its customer base to 45,000 by teaming with Deutsche Post to sign up electricity customers at post offices.

German green power products can be divided into three general categories: pure large hydro, blends of renewables and cogeneration or combined heat and power (CHP), and $100 \%$ renewable energy products. While the pure hydropower products offered early on still dominate in terms of total number of green power customers, the other two categories have recently demonstrated higher growth rates. Initially, marketers priced hydropower products, which are supplied from existing large-scale plants, below generic electricity. However, more recently they have been offered as premium products. A number of marketers have offered blends of renewables and cogeneration. Typically, these include 50-80\% renewable energy with some portion supplied from new renewable sources, while the remainder of the power is supplied from gas-fired CHP plants that are cleaner and more efficient than traditional coal plants. Most marketers offer $100 \%$ renewable products that are typically not more than $75 \%$ large hydro. These generally include a percentage of power from new renewable sources and demand the highest price premiums. 
German green power products are typically priced at premiums ranging from 10$30 \%$ of the total electricity price. ${ }^{4}$ The lowest-priced green power product, offered by LichtBlick, is only $6.7 \%$ more expensive than the average conventional electricity product, whereas the most expensive green power product is priced at almost a $40 \%$ premium. On average, green power products cost $22 \%$ more than conventional power products.

Green power marketing has had some success in Germany's competitive electricity market, with the overall market penetration rate at about $1 \%$. To date, the green power market has been limited to some extent by retail market barriers and strong supply-side government support for renewable generation. Going forward, there are few signs of a near-term boost for green power marketing in Germany. After the initial success of E.On's Aquapower and RWE's early green-pricing programs, the large utilities have returned to less aggressive marketing strategies. It remains to be seen whether the possible involvement of major utilities in planned large offshore wind parks will bring new momentum to the green power market.

\section{Japan}

In the fall of 2000, all ten of Japan's electric utilities began offering their customers the option to contribute to a green power fund to support the development of wind and solar systems. For example, Tokyo Electric Power Company (TEPCO) offers a program through which customers can contribute an additional 500 Yen or more each month through their electricity bills. TEPCO matches customer donations and administers the program, while a nonprofit organization manages and operates the fund [12]. The other utility programs are structured in the same way, except Kansai Electric, which set a minimum contribution level of 100 Yen per month. Some utilities have used conventional media, such as running full-page ads in major newspapers, to advertise their green power programs. Collectively, the utilities have nearly 38,000 customers participating in the green pricing programs [13]. Tokyo Electric has obtained the most customers, with more than 15,000 customers participating as of February 2002.

In Hokkaido, a wind power cooperative collects funds to support the development of new wind projects in the region. Under the program, members can make contributions by adding $5 \%$ to their electricity bills, while nonmembers can contribute directly to the Hokkaido Green Fund. In addition to its contribution program, the cooperative formed Hokkaido Civic Wind to allow members to purchase shares of future wind projects for 500,000 Yen in return for dividends from the sale of electricity from the wind turbines [13].

At least one company markets green power to larger commercial and industrial customers. The Japan Natural Energy Company (JNEC), which was formed in late

\footnotetext{
${ }^{4}$ Because pricing structures differ with respect to fixed fees and per $\mathrm{kWh}$ adders, the comparison is based on the total annual cost for a four-person household consuming 4,000 $\mathrm{kWh}$.
} 
2000 as a joint venture of TEPCO and ten other companies, sells wind energy certificates to business customers. The company has signed contracts to supply wind power to more than 25 large Japanese companies, including Sony, Epson, Toyota, and Hitachi. Under the agreements, JNEC will provide certificates representing a total of 36 million $\mathrm{kWh}$ of wind power at a premium of $4 \mathrm{Yen} / \mathrm{kWh}(\sim \mathrm{US} 3.4 \varnothing / \mathrm{kWh})$ for 15 years. JNEC also plans to expand its marketing activities and has entered into agreements to purchase the output of three additional wind projects with a combined capacity of about $20 \mathrm{MW}[14,15]$.

Utilities and marketers have only recently begun to market green power to customers in Japan. Given the short time that these programs have been offered, it is difficult to assess customer response and the market potential. Nevertheless, with more than 38,000 customers subscribing to the utility programs in the first 16 months, there appears to be consumer interest in green power. However, the impact on renewable energy development is likely to be limited based on experience with contribution programs in other countries. Typically, customer donations are not sizeable enough to support the development of significant renewable energy capacity. In terms of future green power sales, the most likely area for significant growth lies with the commercial and industrial sector. The early success of JNEC indicates an interest on the part of large businesses to purchase green power. However, the debate over the adoption of a renewable portfolio standard creates some uncertainty that may hinder the development of the voluntary green power market.

\section{The Netherlands}

In the Netherlands, green electricity was first introduced in 1995. All 12 electricity distribution companies have offered green power since 1999. Green power sales grew considerably in late 1999 with the help of a marketing and media campaign launched by the World Wildlife Fund (WWF), a global environmental organization. The campaign helped to increase the number of green electricity customers from 100,000 in September 1999 to 140,000 in January 2000 [16]. Since then, demand has been fuelled by tax exemptions for green electricity and heavy advertising by utilities hoping to increase customer loyalty on the eve of competition, as all residential customers gained the ability to switch to a competitive green power supplier as of July 1, 2001.

An estimated 775,000 customers, or about $13 \%$ of residential electricity customers, were purchasing green power as of April 2002 [17]. In some regions the market share is as high as $20 \%$ [18]. The vast majority of customers are buying green power from their incumbent utilities - only about 50,000 customers had switched to alternative suppliers as of the fall of 2001 [19]. Annual green electricity sales are estimated to be greater than the annual generation of renewable energy in the Netherlands. As a result, some utilities have stopped advertising their green power products or have begun wait-listing customers because they could not supply enough domestically generated green electricity, while others have been importing green electricity or green certificates from other European countries. 
The products offered are typically blends of wind, hydro, and biomass resources, often including waste incineration. Three of the national marketers-Nuon, Essent, and Eneco-include a small percentage of solar (1-2\%) in their resource mix. Nuon sells a blend of wind, hydro, and solar at a slight premium of 0.45 eurocents $/ \mathrm{kWh}$ ( US $0.4 \varnothing / \mathrm{kWh}$ ), which is about $8 \%$ more per $\mathrm{kWh} .{ }^{5}$ Essent's green power product is a no-premium blend of domestic biomass, hydro, wind, and solar resources [20]. However, given the constraints of renewable energy generation in the Netherlands and the rapid growth in customer demand, the company may not be able to make the claim that the power is $100 \%$ made in Holland in the future. Eneco sells a blend of biomass, hydro, wind, and solar at a price premium of just under $10 \%$. The company also promises to invest in new wind power projects [21]. Rendo offers a large hydro product supplied from imports. In early 2002, another half dozen green power providers entered the Dutch market.

To date, import activity has included a number of hydro deals, for example, between Nuon and ewz of Switzerland and Eneco and Vattenfall of Sweden, as well as a green certificate deal between Nuon and a landfill gas facility in New Jersey [22]. New government rules on imported power will make hydro imports financially less attractive and we may begin to see an increase in the fraction of power supplied from new renewables in the future. ${ }^{6}$

In 1999, typical premiums were 1-2 eurocents/kWh (-US, 0.9-1.8 $\varnothing / \mathrm{kWh}$ ) [16]. The combination of increasing energy taxes (REB) and the tax exemption for green electricity that took effect on January 1, 2000, has resulted in prices for green electricity-in some cases, below those for conventional electricity. The energy tax increased another $50 \%$ on January 1,2001 , bringing the total amount of the tax to 5.5 eurocents/kWh ( $\sim$ US $5 \notin / \mathrm{kWh})$ for small consumers $(<10,000 \mathrm{kWh} /$ year $)$. Currently, the major green power marketers charge either no premium or a small premium of $1.5-9.5 \%$. One marketer, Energieconcurrent, still sells green electricity at a discount.

The market for green electricity in the Netherlands has been very successful relative to other countries. With steady increases in the number of green customers and the entrance of several new green marketers, it shows signs of continued growth. The challenge going forward is how to meet additional green power demand, given that essentially all existing domestic renewable energy generation has been sold. Up to this point, green power marketing has not resulted in the development of much new renewable capacity. Given the planning constraints in the Netherlands, where there is very high population density, there are two main options: building offshore wind projects or increasing imports. The debate on the issue of offshore projects is in a relatively early stage in the Netherlands [23]. As for imports, the new rules set by the government regarding issuing green certificates for qualified imports of green

\footnotetext{
${ }^{5}$ On an annual basis (including fixed charges), the premium is about $3.6 \%$.

${ }^{6}$ For example, one could imagine Dutch utilities contributing to the development of new wind power in Norway.
} 
electricity could lead to a system where Dutch green power customers support the development of new renewable energy projects in other countries. ${ }^{7}$

\section{Sweden}

Retail energy suppliers have offered green power in Sweden since early 1996, when the market opened to retail competition. Today, more than 50 companies offer green power options to electricity customers across Sweden, and all consumers have access to green power. While most providers generate their own power, about a third of the companies purchase green power from generators and resell it to customers. Many of the green power products are offered by municipal or public utilities.

According to the Swedish Society for the Conservation of Nature (the leading certifier of green power suppliers), green power sales increased 32\% during 2000 to 9.0 TWh $[24,25]$. This figure represents about $6 \%$ of total electricity sales in Sweden. Nonresidential customers, particularly commercial and industrial customers and public agencies, represent a significant portion of green power sales to date. No data are available on the number of customers purchasing green power.

The green power products are generally $100 \%$ renewable energy offerings supplied from either a mix of several renewables, or a single resource, such as hydro or wind. Many companies offer products supplied from existing hydropower projects, with a small portion of the power from new biomass or wind projects. In terms of pricing, a small number of products have been sold at the cost of conventional electricity, while others have held premiums as high as $10-30 \%$. Of the dozen or so products examined, price premiums ranged from 0.5 öre $/ \mathrm{kWh}$ to 6 öre $/ \mathrm{kWh}$ (US $0.05-0.6$ $\phi / \mathrm{kWh})[26]$. The average price premium in 2000 was approximately $1.4 \mathrm{öre} / \mathrm{kWh}$, ( US $0.14 \phi / \mathrm{kWh}$ ), which translates to about an $8-10 \%$ premium over the cost of the electricity (generation portion only) for commercial and industrial customers [27].

There has been significant activity in the Swedish green power market to date, particularly with respect to large nonresidential consumers. Green power sales are equivalent to about $6 \%$ of Sweden's total electricity market. There are a large number of suppliers offering products_-and continued growth appears likely. However, there has been little interest among residential customers thus far. Furthermore, very little new renewable capacity has been installed to meet demand. Many of the products offered to date are supplied with power from existing hydro projects installed before 1996 , with only a small portion (5\%) of power supplied from new renewables. Some additional environmental improvements may result from the requirement that certified hydro facilities contribute to a fund for environmental improvements on impacted rivers. Looking toward the near future, the movement toward replacing existing renewables subsidies with a green certificate-trading system creates some uncertainty

\footnotetext{
${ }^{7}$ However, the majority of renewable capacity in the Netherlands' largest neighboring country, Germany, is subsidized by the German government scheme, so it will not qualify for Dutch green electricity certificates. France and other countries are likely to follow the German system.
} 
for the green power market. Under the current proposal, users would be required to purchase a certain portion of their electricity from renewables starting in 2003. The mandatory purchase requirements could stifle consumer interest in voluntary purchases. However, the details of this program have not yet been developed and the impacts on the green power market remain to be seen.

\section{Switzerland}

Today, more than 100 electric utilities sell green power to about 46,000 customers in Switzerland. The first programs emerged in the mid-1990s when a number of utilities began offering solar power options [28]. Currently, there are about 30,000 households $(1.5 \%)$ and a small number of businesses buying mainly solar power. These green power sales have resulted in the installation of about $5 \mathrm{MW}_{\mathrm{p}}$ of photovoltaics [29] and about the same amount of wind power. The relatively strong demand for these offerings is remarkable given the fact that, on a per-kWh basis, they are typically priced at premiums on the order of 300-500\% above standard rates. However, customers can choose the number of $\mathrm{kWh}$ of solar power that they purchase and thereby adjust the monthly cost. ${ }^{8}$

More recently, as the possibility of retail competition grows, a second generation of green power products have appeared [30]. These rely mainly on hydropower, but provide added environmental value by meeting the criteria of the Swiss green electricity labeling program Naturemade, which requires environmental improvements, minimum flows, and a minimum percentage of power from new renewables (solar, wind, wood, agricultural biogas). Some utilities now also offer two certified products - a low-impact hydro and a new renewables product. About 4800 customers have signed up for the new low-impact hydro products to date.

In summary, the Swiss market is relatively active, with more than 100 green power products available. Consumer response has been on par with most countries, with about $1-2 \%$ of customers purchasing green power. Many of the green power products offered to date have featured solar or relied heavily on existing hydro resources, and thus, only a small amount of new renewable capacity has been developed to serve green power customers. In the coming years, the Swiss green power market is likely to experience continued growth, given the marketing activities of several larger players, an above average consumer willingness-to-pay for renewables, and the availability of certified low-impact hydropower. Growth could also accelerate if the draft electricity market law is accepted in a popular vote in September 2002, as this would allow retail customers to choose green power providers, exempt green power from grid charges, and introduce a disclosure standard for all electricity products.

\footnotetext{
${ }^{8}$ On average, Swiss solar power customers buy $150-200 \mathrm{kWh} / \mathrm{month}$, which is about $5 \%$ of average household electricity consumption.
} 


\section{United Kingdom}

Fourteen green power marketers offer products to customers in the UK today. The total number of customers has recently been estimated to be 45,000 [31]. This compares to a total of roughly 25 million electricity customers in the UK. Most green power offerings originated in the early days of competition in 1989 [32] and have not been aggressively marketed since. Both contribution and energy-based products have been offered. For example, TXU Energi (formerly Eastern Electricity) and London Electricity have offered contribution programs that allow customers to make donations to support the development of renewables, while RSPB Energy (a program launched by the Royal Society for the Protection of Birds in conjunction with Scottish and Southern Energy) allows customers to purchase green electricity to supply their own energy needs (an example of an energy-based product). RSPB, which claims to serve about 7000 customers, offers green power supplied primarily from new landfill gas, wind, and hydropower resources at no price premium.

A number of competitive green power marketers are also active in the UK. Ecotricity serves industrial and commercial customers only, whereas unit [e]nergy and Green Energy (UK) also serve residential customers. Because of high market-entry costs and unfavorable conditions for intermittent renewables, none of these marketers has had significant success obtaining residential customers thus far. Ecotricity focuses on wind energy and distributed generation, whereas unit[e] sells a mix of wind and hydro. Green Energy (UK) claims to offer "renewable energy from wholly British sources" [33], without specifying the fuel mix. In August 2001, a new marketer, Npower, began aggressively marketing a zero-premium green power product in cooperation with the environmental organization Greenpeace. The company, which is a retail subsidiary of the large electric generating company Inogy (formerly National Power), offers a product called 'Juice', which will be supplied from a new offshore wind farm near North Hoyle scheduled for completion in 2003. Until the project is complete, the company will supply its customers with power from existing wind and hydro power plants [34]. Npower has announced a goal of signing up 50,000 customers, which would double the country's greenpower customers if achieved.

Price premiums are difficult to determine because of the differences between the types of products offered (energy and contribution) and the large number of regional tariffs for both conventional and green power. However, we estimate premiums for an average residential customer consuming $4000 \mathrm{kWh} /$ year to vary roughly between 0 and $15 \%$ of the total electricity cost, with the majority of offerings in the $2-10 \%$ range. As noted above, both Npower and RSPB Energy charge no price premium. ${ }^{9}$

Today, competition in the UK retail electricity market is largely price-driven and green electricity has played a minor role. To some extent, the lackluster performance of the green power market can be attributed to a lack of aggressive marketing by the utilities and marketers. However, the recent launch of Npower's 'juice' product might indicate a more positive trend in the market. Npower differs from previous

\footnotetext{
${ }^{9}$ In the commercial customer segment, Ecotricity also follows a no-premium approach.
} 
residential green power marketers in the UK in that it has set aggressive targets regarding customer uptake and new capacity, its product carries no price premium, and it is intensely marketing the product in cooperation with the environmental group, Greenpeace. New green power marketers without utility backing are likely to continue finding the retail market challenging and may be more successful among commercial customers who can benefit from Climate Change Levy exemptions.

\section{United States}

In the US, the first green power products were offered by utilities in regulated electricity markets in the early 1990s. Today, more than 90 utilities in 31 states offer optional green power programs. The number of programs has grown steadily during the past few years, with between 15 and 25 new programs appearing annually. The medium price premium for green power offered through these programs is $2.5 \% / \mathrm{kWh}$. On average, about $1 \%$ of utility customers participate in green power programs, with the most successful programs achieving participation rates in the range 4-7\%. $[35,36]$. Collectively, about 210,000 customers subscribe, including about 2500 business customers.

In addition to utility programs, power marketers also offer green power options to retail customers in states with competitive power markets. The first of these products appeared in the late 1990s when states such as California and Pennsylvania implemented retail access. Today green power marketers offer retail products in Connecticut, Maryland, Massachusetts, New Jersey, Pennsylvania, Rhode Island, Texas, and Virginia. For example, Green Mountain Energy offers electricity generated from blends of hydro, biomass, wind, and solar resources in several states and last year launched a $100 \%$ new wind energy product in Texas. Community Energy, which has teamed with Exelon to market wind energy from several new wind projects in Pennsylvania, recently announced sales to a number of universities and other large commercial customers. Also, a growing number of organizations, including Bonneville Environmental Foundation, PG\&E National Energy Group, Sun Power Electric, and Sterling Planet, market renewable energy certificates products, which do not require customers to switch suppliers.

Collectively, about one-third of US electricity customers have the option to purchase green power directly from a marketer or their utility, while all customers have the ability to purchase certificate-based products. More than 375,000 customers, or about $1 \%$, are purchasing green power currently ${ }^{10}$. While utility programs have generally continued to grow in number and size in recent years, there has been little growth in green power sales to residential customers in competitive markets since the California restructuring debacle. Most recent growth has been fueled by green power sales to large, non-residential customers, partnerships between marketers and

\footnotetext{
${ }^{10}$ In addition, marketers supply an estimated 450,000 customers with 'clean' electricity products in which a small portion of the electricity is generated from renewables (e.g. 1-2\%).
} 
utilities, and sales of certificate-based products that do not require customers to switch suppliers. As of the end of 2001, demand for green power had resulted in the development of about $650 \mathrm{MW}$ of new renewables capacity with another 440 MW under construction or formally announced.

\section{Other countries}

A number of other European countries show some degree of emerging green power marketing activity. In Austria, the electricity market was fully liberalized in October 2001 and some 2500 customers currently buy green power from either new entrants like Oekostrom AG, Alpen-Adria-Energy AG(AAE), and Raiffeisen Ware Austria, or the incumbent utilities. The largest power generator in the country, Verbund, has been active branding its existing hydro and selling it to wholesalers and retailers in Germany, Italy, and Austria.

In Belgium, no significant green power marketing activity has emerged so far, despite the fact that the Flemish region has allowed residential customers to switch to a competitive green supplier since September 2001. However, the country's largest utility, Electrabel, has been active in hydropower marketing and renewable energy certificate trading in other European countries.

In Denmark, the market for residential customers is yet to be opened. A number of municipal utilities offered green pricing schemes in 1998, and recently NESA launched a green power product in cooperation with the Danish Society for the Conservation of Nature. The company is selling a renewable energy product called Naturstrøm, which is a blend of hydro, wind, biomass, and $30 \%$ system electricity. The Swedish Bra Miljöval program certifies the offering. The company has obtained enough supply to serve 40,000 customers, but no data are available regarding consumer response. The Danish government's plans to implement a renewable purchase obligation and a green certificate-trading system have met with strong opposition and have been put on hold. The uncertainty surrounding policy direction appears to be stunting growth in the green power market, as marketers wait for these issues to be resolved.

The green power market in France is in its infancy. In early 2001, Electricité de France (EDF) had reportedly been considering a regional pilot program in North Western France (Lille, Dunkirk), where customers would have been able to purchase green power generated from wind and small hydro at a premium. However, the project was abandoned due to local political opposition.

Ireland, like the Netherlands and Belgium's Flemish region, has also offered residential customers the opportunity to choose a green supplier early on. This has led to green power offerings both from the major incumbent utility, ESB, and a few new entrants, of which Eirtricity has been most successful in acquiring customers and developing new renewable (wind) energy generation capacity. Altogether, some 12,000 customers buy green power in Ireland to date.

In Italy, the country's largest utility, Enel, has formed a subsidiary named Enel GreenPower to address the opportunities of the green power market both in Italy 
and abroad. In 2001, a green power labeling scheme (100\% Energia Verde) was launched in conjunction with the Association of Renewable Energy Generators (APER) and environmental and consumer organizations, but no products have been offered on the market to date.

Norway was one of the pioneers in deregulating its electricity market for all customers in 1995. However, as $99 \%$ of the country's electricity is generated from hydropower, there has been little incentive for marketers to offer differentiated green power products.

Nevertheless, a handful of Norwegian power providers currently offer green power options to customers, and Statkraft has become involved in international hydropower trading. Among others, power marketers in the Netherlands have bought Norwegian hydropower to include it in their domestic green power products.

\section{Summary and conclusions}

Based on our review of international green power markets, we found that nearly two million customers purchase green power worldwide. Table 2 presents market penetration data in terms of both customers and green energy purchases in the most active green power markets. To date, this consumer demand has translated into the development of about $1000 \mathrm{MW}$ of new renewable electric generating capacity. Other key findings from our review are listed below.

- While market penetration rates for green power have typically been about $1 \%$, the most successful markets have achieved penetration rates of between 5 and $15 \%$. Consumer demand for green power has been highest in the Netherlandswhere about $13 \%$ of residential customers have chosen green power-and Sweden, where green power represents about $6 \%$ of all electricity sales. The relative success of the Dutch market can be explained, in part, by aggressive marketing campaigns by utilities and marketers, a restructuring policy that has allowed early access to retail green power suppliers, and tax exemptions for green power purchases. In Sweden, the market has been driven by the availability of large quantities of existing hydropower that can be sold at relatively low prices.

- Customer education and aggressive marketing is necessary. In general, we found that a lack of aggressive and targeted marketing on the part of green power suppliers is one of the most important factors limiting consumer response to these products. Lack of knowledge of green power products is widespread and can best be overcome by combined efforts of existing utilities, new market entrants, labeling organizations, nongovernmental organizations, and perhaps government agencies. Multiple marketing efforts or combined efforts (i.e. environmental organizations teaming with marketers) can raise awareness in the overall market. Equally important is carefully targeting the most promising customer segments using a variety of communication channels that enable customers to understand the new product. Retaining customers by providing them with information on the status of the program and recognizing their participation is also important. 


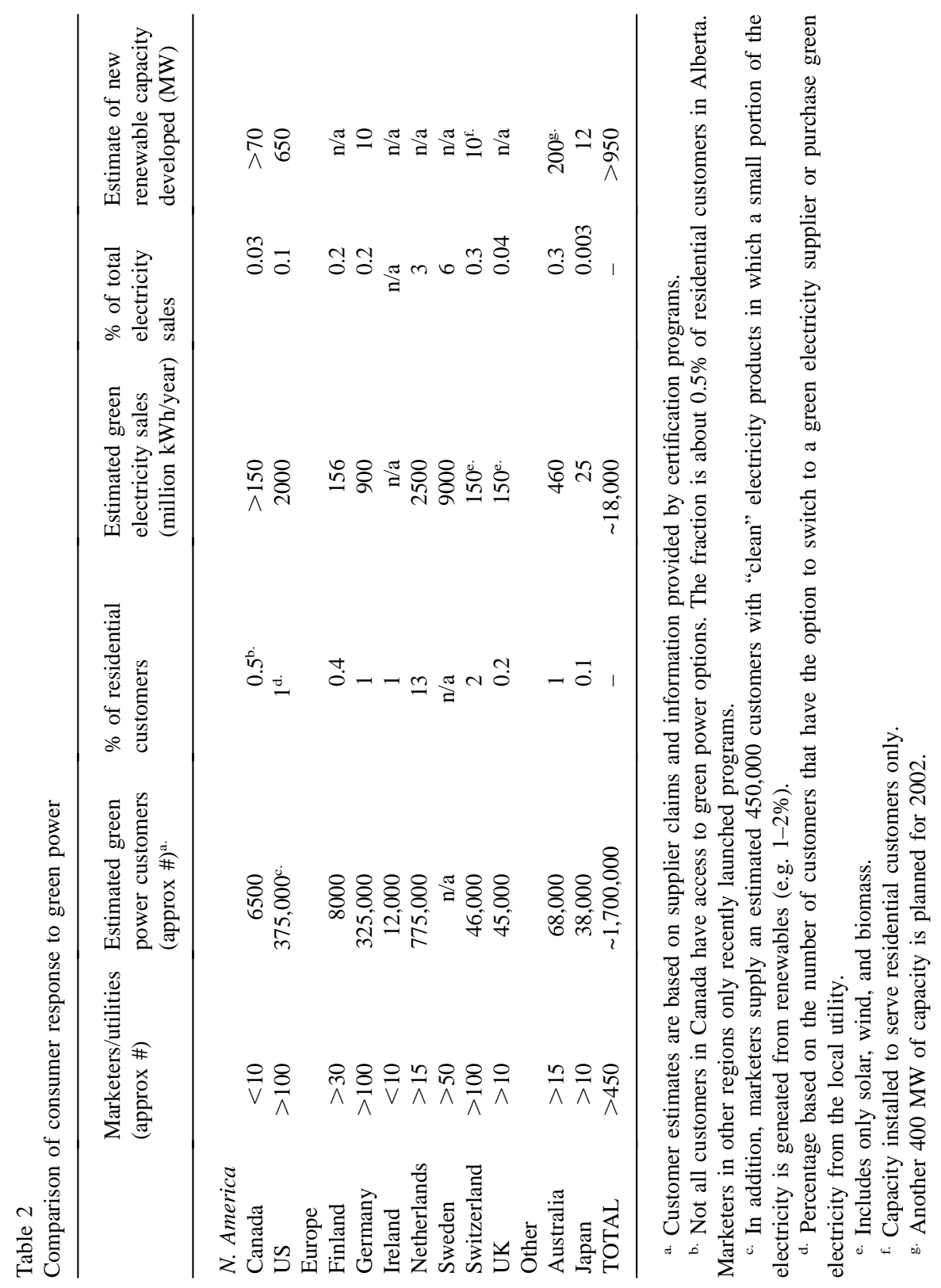


- Green power marketers have offered a range of products to appeal to customers with varying price sensitivities and resource preferences. The majority of products consist of blends of renewable resources, such as biomass, hydro, wind, and solar, offered at low to moderate price premiums. In some European countries, the inclusion of large hydro has been common, whereas most hydropower marketed in other areas has been limited to small or low-impact projects. Generally, products heavily dependent on existing, large hydro resources have been sold at the same price as system power or at very modest premiums, which are then typically used to fund mitigation efforts and environmental improvements at affected waterways. For customers interested in purchasing products that will result in more significant environmental improvements, utilities and marketers have offered products featuring, most commonly, new wind or sometimes solar, with these typically carrying the highest price premiums. In Germany, in particular, cogeneration with natural gas has also been included in green power products, based on its environmental benefits relative to the overall system mix. This demonstrates that there is a certain correspondence between a country's existing power generation structure and the type of green power products that emerge.

- The impact of green power marketing on new renewables development has been limited so far. Much of the green power sold in competitive electricity markets today has been supplied from existing renewable resources. In Europe, large hydropower projects have supplied the bulk of the electricity. A number of programs have led to the installation of new rooftop PV systems; however, these projects are small in terms of overall capacity. In general, the amount of new renewable capacity added to serve green power customers has been limited; although, in many areas, it is expected that additional capacity will be constructed to meet demand as a result of supply deficiencies and requirements for new generation instituted by certification organizations. Already, significant capacity additions are underway in Australia, where certified suppliers are now required to source $80 \%$ of their green electricity sales from new facilities. Overall, there is generally some delay between the launch of programs and the installation of new projects to serve customers. Thus, to some extent, the lack of substantial new capacity reflects the early stage of market development.

- While price is not the only important driver of demand, companies offering lowerpriced products have generally obtained more customers. Most green power products have been offered at modest price premiums on the order of US $0.5 \phi / \mathrm{kWh}$ $1.5 \phi / \mathrm{kWh}$. In some cases, green power has been offered at prices below that of the standard electricity service, such as in Germany, Finland, and the Netherlands. On the other hand, a number of products, typically those that have featured new wind or solar resources, have been offered at relatively high price premiums in the range of US $2 \phi / \mathrm{kWh}-6 \phi / \mathrm{kWh}$ or more. These higher-priced products have been targeted at the most environmentally concerned consumers interested in purchasing high-quality products that yield the greatest environmental benefits. Overall, price appears to significantly influence demand as is evidenced by experience in the Netherlands, Germany, and Sweden; but it is clearly not the only factor. 
In Finland, for example, green power has been offered at a discount to conventional power, yet consumer response has been fairly modest.

- Retail competition can stimulate green power marketing activity. A number of markets experienced a flurry of activity when residential customers first gained access to competitive suppliers. The threat of competition has also spurred incumbent suppliers to offer green energy choices. Prior to the onset of retail competition, utilities have, in many cases, offered green power to their captive customers to encourage customer loyalty when competition ensues and to gain experience marketing differentiated products.

- Many customers have purchased green power without switching suppliers. In countries reviewed in this report, typically less than a third of customers purchasing green power do so through an alternative supplier. This reflects the fact that, in general, switching activity in retail electricity markets has remained low in many countries. Experience from other newly competitive markets, such as telecommunications, suggests that switching is likely to increase over time as markets mature. Thus, one possible explanation for the lack of switching could be the immature nature of the competitive electricity markets considered here. However, because the movement toward competitive electricity markets has slowed in some markets and barriers to switching remain high for residential customers, we may continue to see a majority of customers buy green power from incumbent suppliers.

- Certification and labeling programs can play an important role in shaping products. Certification programs have emerged as important vehicles for verifying renewable energy supplies and ensuring that products have true environmental benefits. Most certification programs have influenced the types of renewables offered and generally led to higher-quality products. A few European certification programs have tried to ensure that some environmental benefit is derived from existing, large hydro projects by requiring suppliers to undertake mitigation activities at affected waterways. Certification organziations have also served as primary drivers for the inclusion of power from new renewable energy sources. Government-sponsored labels have been very successful in both Canada and Australia, while a majority of the labels elsewhere have been created by nongovernmental organizations. Coordination of national labeling approaches and determining how green energy labels and tradable green certificates will interact are emerging issues.

- Government support can be an important facilitator of green power market development. Tax exemptions or credits for green power purchases are one of the most direct forms of government assistance for the green power market. These have been successful in stimulating supply and demand for green power, most notably in the Netherlands. Tax incentives can directly lower the costs of green power and can improve profit margins for marketers, enabling them to more easily compete in the market and undertake more aggressive marketing campaigns. In addition, government commitments to purchase green power have been successful in stimulating markets in some regions.

- The impact of purchase obligations and similar policies designed to support 
renewables is still unclear, but uncertainty in policy development can stifle markets. Countries such as Australia, Belgium, Denmark, Sweden, and the UK have adopted, or plan to implement, purchase obligations (or renewable portfolio standards, as they are know in the US), requiring retail suppliers to obtain some portion of the generation in their resource portfolio from renewables. These policies have the potential to impact consumer demand for green power in that customers might not be willing to pay a premium to green power if a portion of their power is already supplied from renewables. Australia's purchase obligation took effect in 2001 and the impact appears to be negligible so far. Overall, most policies have only recently been adopted and, thus, it is too early to determine their impacts. However, uncertainty surrounding the purchase obligation in Denmark appears to have largely stifled the development of the green power market.

In summary, we find that consumer response rates beyond $10 \%$ are achievable if market conditions are favorable to green power. Most markets, however, have experienced penetration rates of about $1 \%$ or less. In general, green power markets are young and, as is the case with most new markets, require time to develop. Based on our review, the following factors can aid in fostering the development of green power markets: aggressive and cooperative marketing efforts by utilities and competitive providers; incentives and other policies that reduce the cost of renewable energy; restructuring rules that give priority to green power customers; market rules that enable competition to ensue; certification standards that encourage new renewables development; government purchases that stimulate demand; and consumer education that addresses the availability and benefits of green power options.

\section{Acknowledgements}

The authors wish to thank the US Department of Energy's (DOE) Office of Energy Efficiency and Renewable Energy for supporting this research. This paper has benefited from thoughtful review and comments from several international reviewers, namely Allan Andersen, Tore Brænd, Cornelia Brandes, Paula Cribb, Jon Dogterom, Sven Frauenfelder, Larry Goldstein, Heddeke Heijnes, Theresa Howland, Tomas Kaberger, Anne Louise Koefoed, Gero Lücking, Maja Marlier, Mika Ohbayashi, Eveline Steinberger, Ursula Stocker, Blair Swezey, Sven Teske, Sirkka Tepponen, Elaine Waterson. The authors would also like to thank Caroline Hopkins, Philip Lewis, and Andrew Pape-Salmon for information they provided. Lastly, the authors wish to thank Barbara Kündig for research support and Michelle Kubik for her editorial review.

\section{References}

[1] Sustainable Energy Development Authority (SEDA). National Green Power Accreditation Program Quarterly Status Report; June 2000a. 
[2] Cribb P, Saltman N. Personal communication. Sustainable Energy Development Authority, New South Wales, Australia; January 13, 2002.

[3] Sustainable Energy Development Authority (SEDA). National Green Power Accreditation Program Quarterly Status Report; June 2000a.

[4] SEDA. The Green Power Accreditation Program 2000-01: The Unaudited Results. Available from: http://www.greenpower.com.au/download.shtml. 2001.

[5] Available from: http://www.opgdirect.com/content/secure/serving—needs/greenpower/index.asp, accessed April 2002.

[6] Available from: http://micro.newswire.ca/releases/March2002/27/c4780.html/20298-0, accessed April 2002.

[7] Dogterom J. Personal communication. Pembina Institute, Vancouver, Canada; April 26,2002.

[8] Raynolds M, Pape A. The Pembina Institute green power guidelines for canada. Drayton Valley, Alberta: Pembina Institute, 2000.

[9] Pape A. Personal communication. Pembina Institute, Vancouver; October 10, 2001.

[10] University of Vaasa, Department of Marketing. Green electricity in Finland. Vaasa, Finland; 2001. Available from: http://www.vaasaemg.com/index—pricewatchE.html. May 2001.

[11] Tepponen S. Personal communication. Finnish Association for Nature Conservation, Helsinki, Finland; April 24, 2002.

[12] EnergyInfo Source, Inc. Japanese power firms to create green electricity program. Green Power Report; June 26, 2000.

[13] Ohbayashi M. Personal communication, Institute for Sustainable Energy Policies, Tokyo, Japan; December 21, 2001.

[14] Japan Natural Energy Company. First contract under green power certification system. News release April 5, 2001. Available from: http://www,natural-e.co.jp/press1-e.html.

[15] Japan Natural Energy Company (2000) Japan natural energy company limited established. News release; April 5, 2001. Available from http://www.tepco.co.jp/corp-com/press/2000101201-e.html.

[16] Van Vliet B, Wüstenhagen R, Chapells H. New provider-consumer relations in electricity provision. Green electricity schemes in the UK, the Netherlands, Switzerland and Germany. Paper presented at the Business Strategy \& the Environment Conference, Leeds; September 18-19, 2000.

[17] Heijnes H. Greenprices.com. Personal communication. Utrecht, The Netherlands; April 25, 2002.

[18] Ecofys. Electricity from renewable energy sources in the Netherlands: current status and prospects, proprietary report. Utrecht; October 2001.

[19] Available from: www.greenprices.nl/nl/newsitem.asp?nid=231; accessed October 3, 2001

[20] Available from: www.essent.nl/essent/index2.jsp?context-id=0; accessed November 5, 2001.

[21] Available from: www.ecostroom.nl/ecostroominfo/faq.html; accessed November 5, 2001.

[22] Available from: www.greenprices.nl/nl/newsitem.asp?nid=197; accessed August 17, 2001.

[23] Coleman S. Wadden sea project under fire. Het Financieele Dagblad (English); October 3, 2001.

[24] Financial Times. Green sales rise sharply. Renewable energy report, 29 (July): 20, 2001.

[25] Swedish Society for Nature Conservation. Bra Miljöval Certification Program. Goteborg, Sweden. Available from: http://www.snf.se/bmv/english/index.htm; accessed November 2001.

[26] Greenprices.com. Greenprices,com Web site. Available from: http://www.greenprices.com/se. Utrecht, the Netherlands; accessed October 29, 2001.

[27] Financial Times. Demand for green electricity remains strong. Renewable Energy Report, 22 (December): 14, 2000.

[28] Wüstenhagen R. Green electricity in Switzerland. A mere eco-niche or the first step towards a sustainable energy market at large? In: Proceedings International Association for Energyu Economics (eds.): Energy Markets: What's New? Berlin, p. 143-151.

[29] Available from: www.oekostrominfo.ch; accessed April 15, 2002.

[30] Wüstenhagen R, Markard J, Truffer B. Diffusion of green power products in Switzerland, Energy Policy 2002 (in press).

[31] Available from: http://www.greenprices.co.uk/uk/newsitem.asp?nid=253; November 1, 2001.

[32] Lovell H. Green electricity in the UK: a significant new product for the renewable energy industry? Phd thesis. Oxford University. Oxford; September 1998. 
[33] Available from: http://www.greenenergy.uk.com/MainFrameset.asp?page=ProductsPrices.html; February 14, 2002.

[34] Available from: http://www.greenprices.nl/uk/newsitem.asp?nid=201; August 17, 2001. For more information, see http://www.npower.com/html/juiceandwindpower-4467.htm.

[35] Swezey B, Bird L. Utility green pricing programs: What defines success? NREL/TP-620-29831 Golden. CO: National Renewable Energy Laboratory; August, 2001.

[36] Swezey B, Bird L. Green power marketing in the United States: a status report, NREL/TP-62028738. Golden. CO: National Renewable Energy Laboratory; August, 2000.

[37] Bird L, Wüstenhagen R, Aabakken J. Green power marketing abroad: recent experience and trends, NREL/TP-620-32155. Golden. CO: National Renewable Energy Laboratory; April, 2002.

[38] Wüstenhagen R. Ökostrom—von der Nische zum Massenmarkt (Green power marketing-from niche to mass markets). Zurich: vdf Hochschulverlag, 2000. 